〈연구논문(학술)〉

Sodium 2-(2,3-dibromopropionylamino) -5 -(4,6-dichloro-1,3,5triazinylamino)-benzenesulfonate를 이용한 나일론/면 복합소재의 단일 산성염료 일욕염색

\author{
김미경 ${ }^{\dagger} \cdot$ 윤남식 $^{1}$. 김태경 ${ }^{1}$ \\ 한국염색기술연구소, ${ }^{1}$ 경북대학교 섬유시스템공학과
}

\title{
Dyeing of Nylon/Cotton Blend with Acid Dyes Using Sodium 2-(2,3- dibromopropionylamino)-5-(4,6-dichloro-1,3,5-triazinylamino)-benzenesulfonate
}

\author{
Mikyung Kim ${ }^{\dagger}$, Namsik Yoon $^{1}$ and Taekyeong Kim ${ }^{1}$ \\ Korea Dyeing Technology Center, Daegu, Korea \\ ${ }^{1}$ Department of Textile System Engineering, Kyungpook National University, Daegu, Korea
}

(Received: February 29, 2012/Revised: March 12, 2012/Accepted: March 14, 2012)

\begin{abstract}
In order to dye nylon/cotton blended fabrics in solid colors with only acid dyes, a hetero-bifunctional bridge compound (DBDCBS) was examined. The bridge compound was designed to react only onto cotton fabrics first, on which amino-containing acid dyes react later by covalent bonding. By the effect of DBDCBS, amino-containing acid dyes exhibited high affinity toward the cotton fabrics. From the dyeing properties examined at various conditions, the optimum dyeing was decided at $\mathrm{pH} 4$ and $100^{\circ} \mathrm{C}$. Consequently, the solid color was obtained on nylon/cotton blended fabrics in one bath dyeing process using only acid dyes. The DBDCBS did not show any negative effect on nylon side in terms of dyeing and physical properties.
\end{abstract}

Keywords: nylon, cotton, blend, acid dye, one-bath dyeing

\section{1. 서 론}

많은 섬유제품 중 복합섬유 소재 적용은 $100 \%$ 섬유소재의 경제성, 내구성 및 물성의 보완 측면에 서 그 사용량이 점차 증가하고 있다. 복합 섬유소 재 중 나일론/면 복합소재 또는 폴리에스테르/면 복합소재는 경량 슈트, 레져 셔츠, 유니폼, 작업복, 캐쥬얼 의류제품 등으로 사용되며 천연/합섬 복합 섬유소재 중 가장 많이 사용되는 섬유소재이다. 이 러한 복합소재 염색에 있어서 동일색의 염색제품을 획득하기 위해서는 상호간의 오염 발생 우려 및 색 상 재현성 미비 등의 많은 시행착오가 따른다. 또 한 복합소재 제품을 구성하고 있는 각 섬유를 농염 색 하는데 있어서 구성섬유의 포화농도 차이에 기 인하는 농도차로 인한 동일색 발현의 어려움 및 이 온성이 반대인 염료, 조제 사용시 상용성이 나빠 염색 불균일 우려도 있다 ${ }^{1-4,11)}$.
이로 인해 나일론/면 등의 서로 다른 섬유소재로 이루어진 복합소재를 염색할 경우 각각의 소재에 적용 가능한 서로 다른 두 종류 이상의 염료 및 조 제를 사용하여 주로 이욕법이나 일욕이단 염색공정 으로 염색이 이루어진다. 그러나 이러한 복합소재 의 염색방법은 염색공정이 다소 길고 번거로우며 일욕이단 염색법의 경우라도 이욕법에 비해서는 공 정이 단축되나 서로 다른 종류의 염료를 하나의 염 색조에서 사용하므로 서로의 오염으로 인한 염색성 저하의 문제점이 있어 일반 단일소재로 이루어진 직물들에 비하여 염색물의 재현성 확보에 다소 어 려움이 있다 ${ }^{4-7,12)}$.

이에 전보 ${ }^{8-10)}$ 에서는 복합소재의 동색성 염색을 위해 단일염료를 이용한 복합소재의 일욕 염색방법 을 고안하였고, 이를 위해 셀룰로오스 섬유와 공유 결합 가능한 dichlorotriazine기와 아미노기 함유 염 료 등과 공유결합 할 수 있는 $\alpha, \beta$-dibromopropion-

${ }^{\dagger}$ Corresponding author. Tel.: +82-53-350-3910; Fax.: +82-53-350-3887; e-mail: kmk@dyetec.or.kr

(c) 2012 The Korean Society of Dyers and Finishers 1229-0033/2012-03/8-17 
ylamido기를 포함하는 구조로 설계 합성된 이종 이 반응형 화합물인 sodium 2-(2,3-dibromopropionyl-amino) -5-(4,6-dichloro-1,3,5-triazinylamino)-benzenesulfonate (이하 DBDCBS)를 제조하였으며, 아미노기를 포함 한 분산염료가 $\mathrm{DBDCBS}$ 처리 면직물에 우수하게 염색됨을 확인하였다. 또한 서로 다른 소재로 이루 어진 폴리에스테르/면 복합소재의 동색 염색시 두 종류의 염료를 사용해야 했던 일욕염색법과는 달리 합성된 이종 이반응형 브릿지 화합물(DBDCBS)을 이용함으로써 폴리에스테르/면 복합소재의 염색시 한 종류의 분산염료만을 사용하여 서로 다른 두 소 재에 동시에 염색 가능한 완전 일욕염색이 가능함 을 확인하였다.

본 연구에서는 나일론/면 복합소재의 동색 염색공 정에 있어서 기존 염색공정을 보다 개선하고 단순화 시키기 위하여, 이전 연구 ${ }^{8-10)}$ 결과를 토대로 $\mathrm{DBDCBS}$ 합성 화합물과 한 종류의 아미노기 함유 산성염료 만을 사용하여 나일론과 면섬유의 서로 다른 소재 로 이루어진 나일론/면 복합소재에 대한 일욕염색 가능성을 조사하고자 한다. 이를 위해 DBDCBS 처 리 면직물에 아미노기 함유 단일 산성염료의 염색 성을 검토하고 단일 산성염료를 이용한 나일론/면 섬유 복합소재의 일욕 염색방법을 고찰함으로서 기 존의 두 종류의 염료를 사용해야 했던 제한적인 일 욕염색법과는 다른 개념의 나일론/면섬유 복합소재 의 완전 일욕염색법을 고안하고자 한다.

\section{2. 실 험}

\section{1 시료 및 시약}

시료는 KS K 0905에 규정된 시험용 표준 백면포 와 표준 백나일론포 그리고 경위사가 각각 면 섬유 와 나일론 섬유로 이루어진 정련표백된 나일론/면 교직물(Twill, N/C=40/60, 70d/20's, 152×76/inch.)을 사용하였다. 사용염료는 아미노기를 가지는 구조의 산성염료로서 Table 1의 시약용 산성염료인 C.I. Acid Violet 19와 공업용 산성염료인 C.I. Acid Blue 127:1 (Sandolan Mill. Blue N-GLN)을 정제하지 않고 그대로 사용하였다. 이종 이반응형 화합물의 합성에 사용한 2,5-diamino benzenesulfonic acid, 2,3-dibromopropionyl chloride 그리고 2,4,6-trichloro-1,3,5-triazine을 비롯한 그 외 각종 시약은 1 급 시약을 그대로 사용하였다.

\section{2 이종 이반응형 화합물의 합성 ${ }^{8)}$}

전보 ${ }^{8)}$ 의 실험에서와 마찬가지로 2,5-diaminobenzenesulfonic acid, 2,3-dibromopropionyl chloride 그리고 2,4,6-trichloro-1,3,5-triazine을 동일 몰당량으로 ice-bath
에서 반응시켜 Sodium 2-(2,3-dibromopropionylamino) -5-(4,6-dichloro-1,3,5-triazinylamino)-benzenesulfonate (이하 DBDCBS)(Fig. 1)를 합성하였다.<smiles>O=C(Nc1ccc(Nc2nc(Cl)nc(Cl)n2)cc1S(=O)(=O)O)C(Br)CBr</smiles>

Fig. 1. Structure of DBDCBS.

2.3 아미노기 함유 산성염료를 이용한 $\mathrm{DBDCBS}$ 처리 면직물의 염색

2.3.1 면섬유에 대한 DBDCBS의 처리

아미노기 함유 산성염료를 사용하여 염색하기에 앞서 각 $1.0 \mathrm{~g}$ 의 면직물(KS K 0905 표준백면포)에 대해 $10 \%$ o.w.f.의 $\mathrm{DBDCBS}$ 그리고 각각 $10 \mathrm{~g} / \ell$ 와 $200 \mathrm{~g} / \ell$ 농도의 탄산나트륨과 황산나트륨을 사용하 여 욕비 $1: 20$ 의 조건에서 $30^{\circ} \mathrm{C}, 60$ 분간 처리한 후 $80^{\circ} \mathrm{C}$ 이상의 증류수로 3 회 이상 수세하여 미고착 $\mathrm{DBDCBS}$ 를 완전히 제거하였다.

2.3.2 $\mathrm{DBDCBS}$ 처리 전, 후 면직물의 산성염료에 의한 염색

$\mathrm{DBDCBS}$ 가 처리된 면직물 및 미처리 면직물 $1 \mathrm{~g}$ 을 욕비 1:50의 조건으로 Table 1의 아미노기 함유 산성 염료 2종인 C.I. Acid Blue 127:1(Sandolan Mill. Blue $\mathrm{N}-\mathrm{GLN}$ )과 C.I. Acid Violet 19을 각각 $5 \%$ o.w.f. 사용하 여 $\mathrm{pH} 4$, 욕비 $1: 50$ 의 조건으로 $100^{\circ} \mathrm{C}$ 에서 60 분간 염색한 후 $60^{\circ} \mathrm{C}$ 에서 20 분간 소핑 및 수세, 건조하여 DBDCBS 처리 및 미처리 면직물의 염색성을 비교하 였다. 그리고 이들 염색물의 결합특성을 확인하고자 $100 \% \mathrm{DMF}$ (Dimethylformamide) $20 \mathrm{ml}$ 를 사용해 $90^{\circ} \mathrm{C}$ 이 상에서 1 시간 추출하여 미고착 염료를 완전히 제거 한 후 아미노기 함유 산성염료와 $\mathrm{DBDCBS}$ 처리 면 직물 및 미처리 면직물간의 결합특성을 검토하였다.

\subsection{3 $\mathrm{DBDCBS}$ 의 처리 면직물의 산성염료에 의한 조건별 염색}

$\mathrm{DBDCBS}$ 로 처리된 면직물 $1.0 \mathrm{~g}$ 을 욕비 $1: 50$ 의 조 건으로 각 염료농도( $0.5 \sim 25 \%$ o.w.f.), 염색온도(50 $\left.110^{\circ} \mathrm{C}\right)$ 그리고 $\mathrm{pH}(3 \sim 11)$ 조건을 달리하여 염색하였 다. 염색이 끝난 후 $60^{\circ} \mathrm{C}$ 에서 20 분간 소핑하여 미고 착된 염료를 완전히 제거하고 증류수로 수세, 건조 한 후 이들의 색상강도를 측정하였다. 
Table 1. Acid dyes contaning amino groups used in experiments

C.I. Acid Blue 127:1

2.4 단일 산성염료에 의한 나일론/면 복합소재의 조건별 일욕염색

\subsection{1 단일 산성염료에 의한 나일론 섬유와 면섬유 단독직물의 일욕염색}

$\mathrm{DBDCBS}$ 가 적용된 나일론/면 복합소재에 대하여 한 종류의 산성염료만을 이용한 일욕염색 방법 가 능성을 우선적으로 확인하기 위해 나일론/면 복합소 재를 구성하는 나일론 섬유와 면섬유 두 소재의 모델 섬유소재로서 표준백포인 백면포와 백나일론포 각 단독직물을 별도로 준비하여 동일욕 내에 동시 투입 하여 $\mathrm{DBDCBS}$ 처리 및 염색함으로써 각 소재별 염 색성을 검토하였다. DBDCBS 처리와 염색은 Fig. 2의 One-bath process 일욕염색법을 이용하여 DBDCBS가 처 리되지 않은 일반 면직물과 일반 나일론 직물 각 $0.5 \mathrm{~g}$, 그리고 $10 \%$ o.w.f.의 DBDCBS를 하나의 pot에 동시 투입하여 욕비 $1: 20$ 으로 고정된 $10 \mathrm{~g} / \ell$ 의 탄산나 트륨과 $200 \mathrm{~g} / \ell$ 의 황산나트륨이 가해진 알칼리 조건의 저온(상온)에서 $0.5^{\circ} \mathrm{C} / \mathrm{min}$ 의 승온속도로 서서히 승온 시킨다. 처리온도가 $50^{\circ} \mathrm{C}$ 에 도달한 즉시 동일 염욕내 의 $\mathrm{pH}$ 를 4로 조정하고 Table 1의 아미노기 함유 산 성염료 C.I. Acid Blue 127:1(Sandolan Mill. Blue N-GLN) 와 C.I. Acid Violet 19 를 각각 투입한 후 $3{ }^{\circ} \mathrm{C} / \mathrm{min}$ 의 속도로 승온시켜 60 분간 염색함으로써 일욕상에서 연속적으로 $\mathrm{DBDCBS}$ 처리와 염색이 모두 이루어지 도록 하였다.

\section{4 .2 단일 산성염료에 의한 나일론/면 교직물의 일욕염색}

앞서 나일론 섬유와 면 섬유 소재로 각각 이루어 진 두 가지 단독직물에 대한 일욕염색성 검토 결과를 경위사 각각 나일론 섬유와 면섬유로 제직된 나일론/ 면 교직물의 일욕염색에 직접적으로 적용함으로써 한 종류의 산성염료만을 사용하여 $\mathrm{DBDCBS}$ 가 적용된 나일론/면 교직물의 일욕염색 특성을 조사하였다.

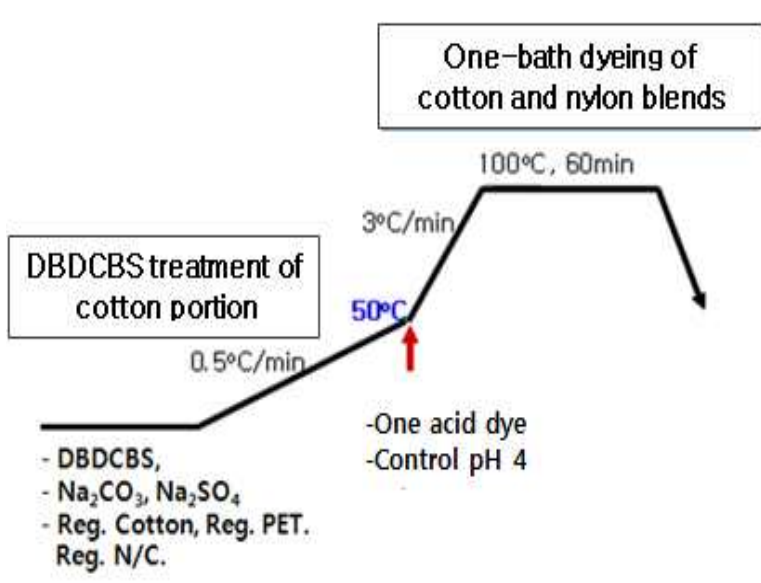

Fig. 2. One-bath dyeing process of nylon/cotton blends.

DBDCBS 처리와 염색은 실험 2.4.1과 동일한 Fig. 2의 One-bath process 일욕염색 방법을 이용하여 일반 나 일론/면 교직물 각 $1.0 \mathrm{~g}$, 그리고 $10 \%$ o.w.f.의 DBDCBS 를 하나의 염욕에 동시 투입하고 저온의 알칼리 조 건에서 $\mathrm{DBDCBS}$ 가 면 섬유 부분에 처리되도록한 후 $\mathrm{pH} 4$ 조건으로 맞춘 동일욕 내에 한 종류의 산성 염료만을 즉시 투입하여 염색함으로써 일욕상에서 연속적으로 $\mathrm{DBDCBS}$ 처리와 염색이 모두 이루어지도 록 하였으며, 이들의 염색성을 $\mathrm{DBDCBS}$ 를 처리하지 않은 나일론/면 교직물의 일욕염색물의 경우와 비 교하였다.

\section{4 .3 단일 산성염료에 의한 나일론/면 복합소재의 염색 조건별 일욕염색}

나일론/면 교직물의 One-bath process 일욕염색 특 성을 확인하기에 앞서 나일론/면 교직물을 구성하 는 두 섬유소재가 일욕에서 한 종류의 산성염료로 조건별 염색시 서로간의 염색성에 영향을 끼치는지 알아보기 위하여 나일론/면 교직물을 구성하는 서 로 다른 소재인 나일론 섬유와 면섬유 단독직물을 
별도로 준비해 하나의 염욕에 DBDCBS와 함께 동 시 투입하여 각 염색조건별로 일욕염색한 후 두 소 재의 염색성을 조사하였으며, 이를 나일론/면 교직 물의 일욕염색에도 적용함으로써 완전 일욕염색의 최적 처리조건을 확인하였다.

나일론 섬유와 면섬유 단독직물 또는 나일론/면 교직물의 One-bath process에 의한 조건별 염색시 2 종의 각 산성염료 농도범위는 $0.5 \sim 20 \%$ o.w.f., 처 리온도는 $50 \sim 120^{\circ} \mathrm{C}, \mathrm{pH}$ 는 $3 \sim 11$ 그리고 염색시간 범위는 $10 \sim 120$ 분으로 달리하여 각 조건별로 염색 하였으며, 염색이 끝난 후 $80^{\circ} \mathrm{C}$ 에서 20 분간 소핑 $(\mathrm{RF}-101,1 \mathrm{~g} / \ell)$ 하여 미고착된 염료를 완전히 제거하 고 증류수로 수세한 후 건조하였다. 각 조건별로 염색방법은 $3 \%$ o.w.f.농도의 각 산성염료를 사용하 여 $100^{\circ} \mathrm{C}$ 에서 60 분간 염색하는 것을 기준으로 하였다.

\section{5 염색물의 색농도 측정}

모든 염색물의 겉보기 색농도는 측색기(Datacolor SF 600 Plus, Datacolor, USA)를 사용하여 측정하였 으며, $380 \sim 720 \mathrm{~nm}$ 의 파장영역에서 $10 \mathrm{~nm}$ 간격으로 측정된 $\mathrm{K} / \mathrm{S}$ 값으로 부터 Total $\mathrm{K} / \mathrm{S}$ 를 산출하였다.

$2.6 \mathrm{DBDCBS}$ 처리에 의한 일욕염색 나일론/면 교직물의 인장강도 평가

$\mathrm{DBDCBS}$ 에 의한 면직물의 취화여부를 확인하기 위하여 $\mathrm{DBDCBS}$ 가 처리된 나일론/면 교직물에 대해 2종의 아미노기 함유 산성염료(Table 1) $5 \%$ o.w.f. 를 사용하여 $100^{\circ} \mathrm{C}$ 에서 60 분간 일욕염색한 후 이들 직물의 인장강도를 측정하여 염색되지 않은 일반 교직물과 비교하였다. 산성염료/면 교직물의 일욕 염 색 전, 후 인장강도는 $\mathrm{KS} \mathrm{K} 0520$ : 2004 그래브법 C.R.E Type 방법을 이용하여 파지거리는 $76 \mathrm{~mm}$ 으 로 하여 측정되었다.

\section{3. 결과 및 고찰}

3.1 아미노기 함유 산성염료를 이용한 $\mathrm{DBDCBS}$ 처리 면직물의 염색특성

합성된 $\mathrm{DBDCBS}$ 화합물의 화학구조는 두 개의 반 응성기를 가지고 있다. 하나는 dichlorotriazine계의 반응기로서 상온 $\left(30 \sim 40^{\circ} \mathrm{C}\right)$ 의 알칼리 조건에서 셀룰 로오스 섬유와 쉽게 공유결합을 형성하는 반응기이 며, 다른 한쪽은 $\alpha, \beta$-dibromopropionylamido 반응기 로서 고온 $\left(90^{\circ} \mathrm{C}\right.$ 이상 $)$ 의 산성조건에서 아미노기 $\left(-\mathrm{NH}_{2}\right)$ 와 반응가능한 반응기이다. 이를 면섬유에 적용하는 경우 두 반응기의 반응조건은 완전히 반대이고, $\alpha, \beta$ -dibromopropionylamido 반응기는 면섬유 또는 하이드록
실기 등과는 반응하지 않으므로 dichlorotriazine 반응 기가 면섬유에 반응하는 동안 손상되지 않고 남아 있게 되고 이 반응기에 아미노기 함유 물질의 결합 이 가능할 것으로 보인다. 산성염료의 경우 화학구 조 내에 $-\mathrm{NH}_{2}$ 기가 포함되어 있는 경우가 다수 있 다. 따라서 본 연구에서는 $\mathrm{DBDCBS}$ 를 사용하여 $\mathrm{DBDCBS}$ 가 면섬유에 먼저 고착된 후 아민기를 함 유하는 산성염료가 $\mathrm{DBDCBS}$ 처리된 면섬유에 공유 결합하여 반응염색됨으로써 나일론 섬유와 면섬유 복합소재에 대하여 단일 산성염료만을 이용하여 두 소재 모두 일욕에서 염색가능한 것으로 판단된다.

Fig. 3과 Fig. 4는 먼저 DBDCBS가 처리된 면직 물에 아미노기 $\left(-\mathrm{NH}_{2}\right)$ 를 가지는 산성염료의 공유결합 에 의한 반응염색 여부를 확인하기 위해 $\mathrm{DBDCBS}$ 처리 및 미처리 면직물에 대하여 아미노기 함유 산 성염료 Acid Blue 127:1과 Acid Violet 19를 사용하여 염색한 후 고온의 $\mathrm{DMF}$ 에서 처리하여 단지 흡착만 되거나 미고착된 염료를 완전히 제거하고 이들 염색

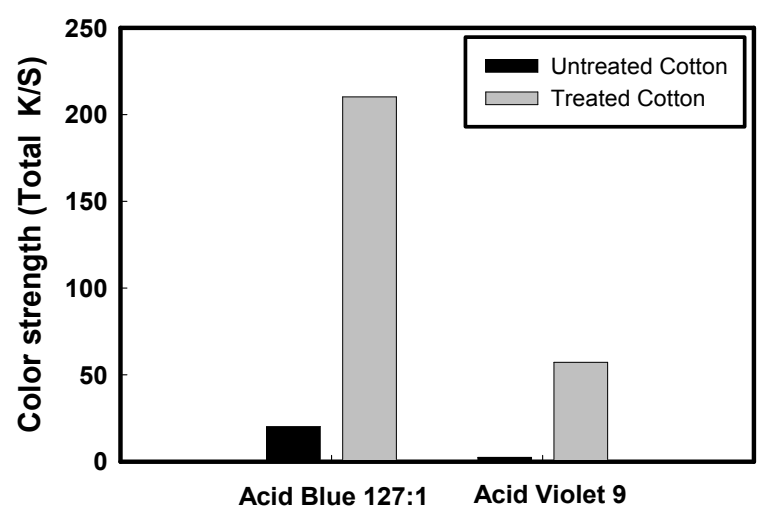

Fig. 3. Color strength of acid dye on untreated and treated cotton fabrics by DBDCBS.(DBDCBS ; 10\% o.w.f., Dye ; 5\% o.w.f., Temp. ; $100^{\circ} \mathrm{C}$, Liq. Ratio ; $\mathrm{pH} 4,1: 50)$

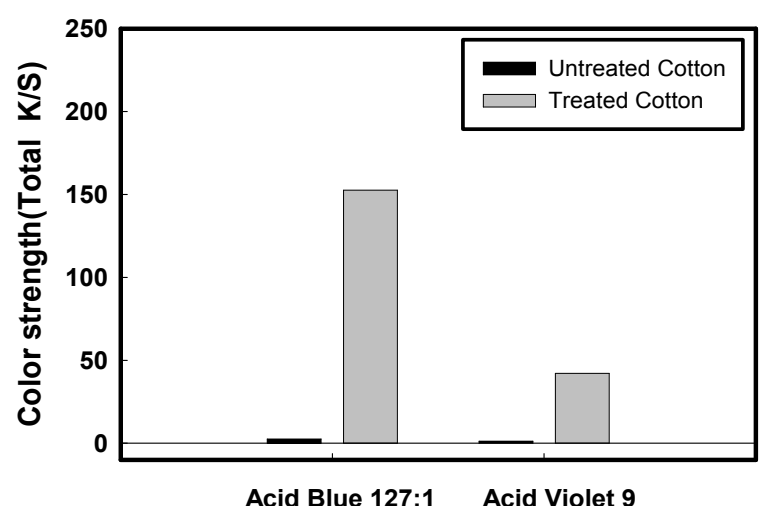

Fig. 4. Color strength of acid dyes on the DBDCBS treated-cotton and untreated-cotton fabric after removing the unfixed dye with DMF. 
물의 색농도를 측정, 비교한 것이다. 그 결과 $\mathrm{DBDCBS}$ 처리된 면직물의 경우 적용 산성염료에 의해 농색 으로 염색된 반면 미처리 면직물의 경우 거의 염색 이 되지 않음을 확인할 수 있다.

일반적으로 음이온성 염료인 산성염료는 나일론 또는 양모와 같이 섬유구조 내의 아미노기 말단기 에 양이온으로 하전되는 부분이 있는 섬유와 정전 기적 인력으로 이온결합이 이루어지며, 셀룰로오스 섬유에 대해서는 거의 친화력이 없거나 미량 흡착 되며 소핑, 수세 과정에서 대부분 탈착이 이루어진 다. 그러므로 일반 면섬유에 대해서 친화력이 거의 없는 산성염료는 $\mathrm{DBDCBS}$ 미처리 면직물에 대하여 당연히 대부분 염착되지 않을 뿐만 아니라 수세과 정과 고온의 $\mathrm{DMF}$ 처리에 의해서도 미고착 염료는 대부분 탈착되었다.

반면에 DBDCBS 처리 면직물의 경우는 아미노기 함유 산성염료에 의한 염색성이 우수하게 나타날 뿐만 아니라 염색한 후 고온의 DMF 처리에 의해 서도 섬유상 고착된 염료는 거의 탈착되지 않는다. 이는 DBDCBS 분자내의 dichloro-s-triazinyl 반응기 가 면직물의 하이드록실기와 공유결합을 형성하며, 이때 손상되지 않고 $\mathrm{DBDCBS}$ 분자 내에 안정하게 남아있는 $\alpha, \beta$-dibromopropionylamido기가 이후 고온 산성조건에서 아미노기를 가지는 산성염료와 안정 적인 결합을 이룬 것으로 보인다. 따라서 $\mathrm{DBDCBS}$ 가 처리된 면섬유의 경우는 분자 내 아미노기를 가 지는 산성염료와 견고한 공유결합을 형성함으로써 반응염색이 이루어짐을 알 수 있다.

\section{$3.2 \mathrm{DBDCBS}$ 처리 면직물의 산성염료 처리 조건 별 염색특성}

$\mathrm{DBDCBS}$ 처리 면직물에 대한 2종의 아미노기 함 유 산성염료(Acid Blue 127:1, C.I. Acid Violet 19)의 최 적 염색조건을 확인하기 위해 각 온도별, $\mathrm{pH}$ 별 염색 성과 빌드업성을 조사하였다.

Fig. 5는 DBDCBS 처리 면직물에 대한 2종의 아 미노기 함유 산성염료의 $\mathrm{pH}$ 별 염색성을 나타낸 것 으로 그 결과 사용한 모든 산성염료에 있어서 알칼 리영역 보다는 산성영역으로 갈수록 산성염료의 염 착성이 증가하는 것을 알 수 있다.

이것은 산성조건 하에서 $\mathrm{DBDCBS}$ 분자 말단에 위치하고 있는 브롬과 산성염료의 아미노기가 치환 반응에 의해 반응이 진행되기 때문이다. C.I. Acid Violet 19 의 경우는 $\mathrm{pH}$ 의 영향을 가장 많이 받아 중성 영역 이상 알칼리 영역으로 갈수록 염착성이 급격히 감소함을 알 수 있으며, Acid Blue 127:1은 밀링형 산성 염료로서 $\mathrm{pH}$ 의 영향을 보다 적게 받아 알칼리 영역에
서 염색성의 감소현상은 Acid Violet 19보다 크지 않다. 또한 $\mathrm{DBDCBS}$ 분자 구조 내에는 설폰기로 부터 유 도되는 음이온기가 존재하여 산성조건에서 일시적 으로 산성염료의 아미노기가 양이온화 되어 서로간의 정전기적 인력에 의한 흡착성이 증가하여 $\mathrm{DBDCBS}$ 처리 면섬유 내의 더욱 많은 $\alpha, \beta$-dibromopropionylamido기가 산성염료의 아미노기와의 반응에 참여할 수 있게 되는 것으로 보인다.

Fig. 6은 2종의 아미노기 함유 산성염료의 온도별 염색성을 조사하기 위해 $50 \sim 110^{\circ} \mathrm{C}$ 의 온도구간에서 60 분 동안 염색한 후 이들의 염색성을 나타낸 것으 로 온도가 높아질수록 염색성이 점차적으로 증가하 여 $100^{\circ} \mathrm{C}$ 이상에 이르러 거의 최대 염착성을 나타내 고 있다. 이는 일반적으로 면직물에 처리된 $\mathrm{DBDCBS}$ 가 가진 $\alpha, \beta$-dibromopropionylamido 반응기는 주로 고온에서 반응이 이루어지기 때문인 것으로 보인다.

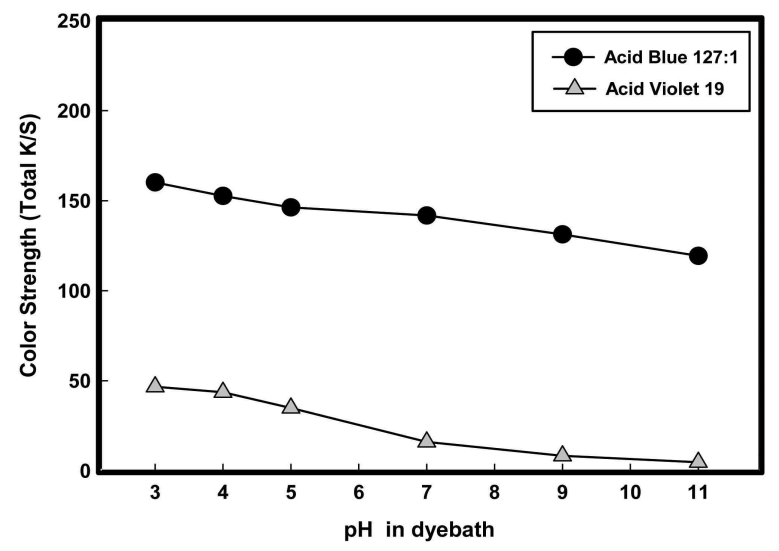

Fig. 5. Effect of $\mathrm{pH}$ on the dyeing with acid blue 127:1 and Acid violet 19 of cotton fabrics treated with the DBDCBS.(DBDCBS ; 10\% o.w.f., Dye ; 3\% o.w.f., Temp. ; $100^{\circ} \mathrm{C}$, Time ; 60min)

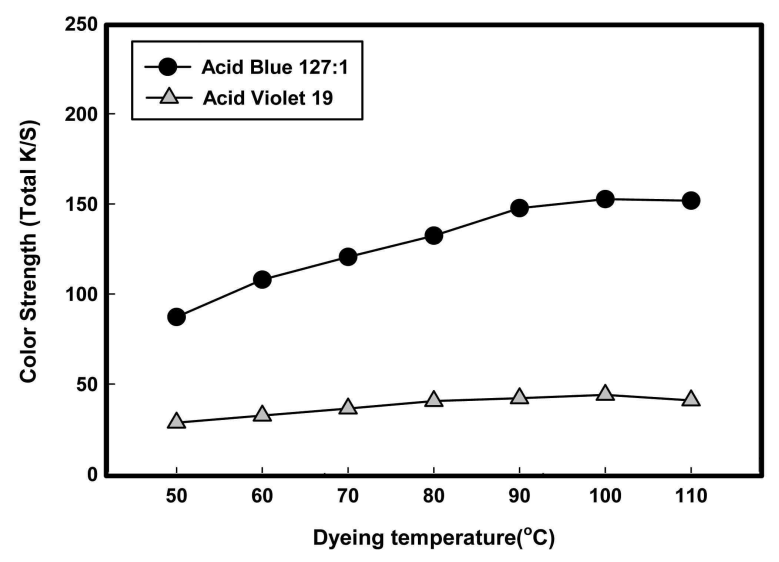

Fig. 6. Effect of dyeing temperature on the dyeing with Acid blue $127: 1$ and Acid violet 19 of cotton fabrics treated with DBDCBS.(DBDCBS ; 10\% o.w.f., Acid blue 127:1 ; 3\% o.w.f., pH ; 4, Time ; 60min) 
Fig. 7은 DBDCBS 처리 면직물에 대한 2종의 각 아미노기 함유 산성염료의 빌드업성을 조사하여 나 타낸 것으로 $\mathrm{DBDCBS}$ 처리 면직물에 대하여 모든 산성염료의 염착량은 염료의 농도가 증가할수록 지 속적으로 증가하다가 $10 \sim 15 \%$ o.w.f.이상에서는 완 만하게 증가하고 있어 거의 평형에 이른다. 전체적 으로 Acid Blue 127:1 염료를 적용한 경우 색상강도가 매우 높아 $\mathrm{DBDCBS}$ 처리 면직물에 대한 염착성이 매우 우수함을 알 수 있으며 C.I. Acid Violet 19의 경우 는 색상강도가 보다 낮게 나타나 중담색 수준의 염착 성을 보이고 있다.

이로서 셀룰로오스 섬유와 공유결합 가능한 dichloro -s-triazinyl기와 아미노기 함유 산성염료를 공유결합 할 수 있는 $\alpha, \beta$-dibromopropionylamido기의 두 가지 반응성기를 포함하는 구조로 설계된 이종 이반응형 화합물인 $\mathrm{DBDCBS}$ 처리 면직물을 선별된 2종의 아 미노기를 포함한 산성염료를 이용하여 염색한 경우 염색성이 우수하게 나타남을 확인하였다.

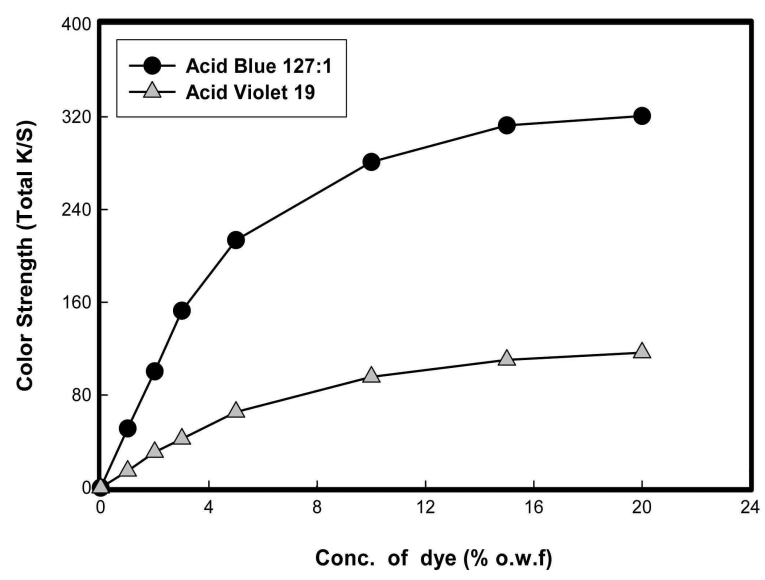

Fig. 7. Build-up properties of Acid blue 127:1 and Acid violet 19 on cotton fabrics treated with the DBDCBS. (DBDCBS ; 10\% o.w.f., pH ; 4, Temp. ; $100^{\circ} \mathrm{C}$, Time ; 60min)

3.3 아미노기 함유 산성염료에 의한 나일론/면 복합소재의 일욕염색성

\subsection{1 나일론 섬유와 면 섬유 단독직물의 일욕염색 특성}

선행된 DBDCBS 합성 화합물이 적용된 면섬유를 활용하여 나일론/면 등의 복합소재 염색시 산성염 료와 반응성 염료 2종의 염료를 별도로 사용해야하 는 기존의 이욕 염색법 보다 하나의 염료만을 사용 하여 염색공정이 개선된 완전 일욕염색이 가능할 것으로 보인다. 즉, 나일론 섬유와 면섬유 복합소재 에 대해서 단일 산성염료만을 사용하여 나일론 섬
유에 대해서는 이온결합성을 가지는 원래의 산성염 색 메카니즘으로, 면섬유는 $\mathrm{DBDCBS}$ 에 의해 반응염 색 메카니즘으로 염색되므로 두 가지 소재 모두 일 욕에서 동시에 염색이 이루어질 것이며 그 염색조 건도 동일한 산성조건에서 고온염색 방식으로 염색 이 가능한 일욕염색법이 실현될 것으로 예상된다.

이를 확인하기 위하여 나일론/면 교직물을 이루는 나일론 섬유와 면섬유 소재의 각 단독직물을 별도 로 준비하고 $\mathrm{DBDCBS}$ 와 함께 하나의 염욕에 동시 투입하여 저온에서의 면섬유 부분에 $\mathrm{DBDCBS}$ 처리 과정 이후 동욕에서 연속적으로 Acid blue 127:1의 단 일 산성염료를 사용하여 일욕염색(One-bath process)하는 경우 온도별, 농도별, $\mathrm{pH}$ 별의 각 염색조건별로 염색 하여 두 직물간 염색성을 검토하였으며, 이러한 일욕 염색시 나일론/면 교직물을 이루는 두 소재간의 염색 성 영향을 알아봄으로써 나일론/면 교직물을 이루는 두 소재의 단일 산성염료를 이용한 One-bath process 일욕염색 적용 가능성을 검토해 보고자 하였다.

Fig. 8은 Acid blue 127:1을 이용하여 One-bath process 일욕염색 방식으로 한 염욕 내에서 일욕염색한 각 면 직물과 나일론 직물의 온도별 염색성을 비교하여 나타낸 것으로 나일론 직물과 면직물 모두 온도가 증가할수록 색상강도가 증가하여 나일론 직물의 경 우는 $90 \sim 100^{\circ} \mathrm{C}$ 에서 거의 염색평형에 도달하고 면 직물의 경우도 염색온도가 증가할수록 색상강도가 점차 증가하여 $100^{\circ} \mathrm{C}$ 이상에서 최대의 염착성을 나 타내고 있다. 그러므로 나일론 직물과 DBDCBS 처 리 면직물의 염색성을 고려하여 앞으로 이들 복합 소재의 염색에 있어서 처리조건을 $100^{\circ} \mathrm{C}$ 로 처리하 는 것이 적당할 것으로 보인다. 나일론 직물은 $\mathrm{DBDCBS}$ 처리 면직물보다 약간 높은 색상강도를 나타내고 있지만 $\mathrm{DBDCBS}$ 가 처리된 면직물의 경우에도 이에

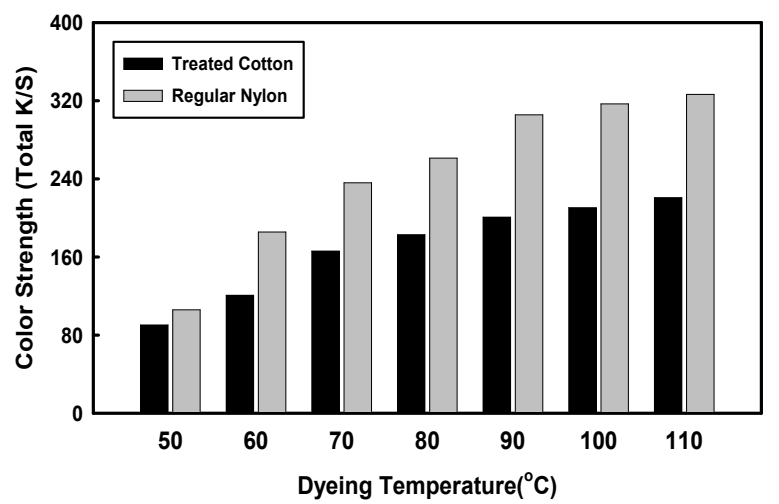

Fig. 8. Effect of dyeing temperature on the dyeing with Acid Blue 127:1 of DBDCBS treated cotton and nylon fabrics. (DBDCBS ; 10\% o.w.f., Dye ; 5\% o.w.f., pH ; 4 , Time ; 60min) 
대한 염착성이 비교적 우수하게 나타나 두 직물간 의 염색성 차이는 크지 않다. 전체적으로 나일론에 비하여 면직물의 색상강도는 약간 떨어지지만 복합 소재의 염색에 있어서 충분한 강도의 색상부여가 가능할 것으로 보인다.

이처럼 면직물에 대한 $\mathrm{DBDCBS}$ 처리가 저온에서 비교적 안정적으로 이루어져 고온의 조건에서 아미노 기 함유 산성염료는 일욕내에서 나일론 뿐만 아니라 면직물에도 견고하게 결합될 수 있음을 알 수 있다.

Fig. 9는 일반 면직물과 일반 나일론 직물에 대 하여 일욕염색시 $\mathrm{DBDCBS}$ 를 일욕 내에 동시 투입 시켜 저온에서 처리한 후에 Acid Blue 127:1 염료농 도별 단독직물들의 염색성을 조사하여 나타낸 것이 다. 그 결과 $\mathrm{DBDCBS}$ 처리 면직물에 대하여 적용 Acid Blue 127:1 염료농도 5\% o.w.f.이하에서는 거의 직선적으로 증가하다가 그 이상에서는 거의 다소 완만하게 증가하고 있다. 나일론 섬유의 경우 전체 적으로 염료의 농도가 증가할수록 염색성이 증가하 다가 5\% o.w.f.이상에서는 매우 완만하게 증가하고 있음을 알 수 있으며 대부분의 농도에 걸쳐 일반 나일론 직물보다 DBDCBS 처리 면직물의 염색성이 약간 낮게 나타나고 있다.

Fig. 10은 일반 면직물과 일반 나일론 직물 그리고 $\mathrm{DBDCBS}$ 를 일욕 내에 동시 투입시켜 DBDCBS 처리 이후 즉시 동일욕 내에 Acid Blue 127:1 산성염료를 투입하고 초산과 탄산나트륨을 사용하여 $\mathrm{pH}$ 를 3 11 까지의 범위 내에서 변화시켜가며 염색성을 조사하 여 나타낸 것이다. 그 결과 $\mathrm{DBDCBS}$ 가 처리된 면직 물의 경우는 알칼리영역 보다는 산성영역으로 갈수 록 산성염료의 염착성이 크게 증가하는 것을 알 수 있다. 나일론 직물의 경우는 당연히 산성염료에 의한 메카니즘대로 산성영역에서 염색성이 다소 높게 나 타나고 있으나 면직물에서보다는 $\mathrm{pH}$ 의 영향이 더욱 커서 알칼리로 갈수록 염색성이 현저히 감소됨을 알 수 있다. 한편, $\mathrm{pH}$ 3의 고온 산성 염욕조건에서는 면 직물에 대한 취화현상이 발생할 우려가 있으므로 이 들 복합소재의 염색에 있어서 염욕 내의 $\mathrm{pH}$ 는 4 로 하는 것이 적당할 것으로 보인다.

Fig. 11은 면직물과 나일론 직물의 각 단독직물 의 일욕염색시 Acid Blue 127:1 산성염료를 사용하여 One-bath process 일욕염색법으로 동시에 염색하는 경우 염색 시간별 염색성을 나타낸 것으로 두 단 독직물 모두 사용한 모든 염료에 있어서 염색시간 20 30분 이내에 거의 평형에 도달함을 알 수 있다.

이상에서 살펴본 바와 같이 일욕 내에서 나일론 직물과 $\mathrm{DBDCBS}$ 처리된 면직물은 아미노기를 가지는 산성염료에 대하여 산성조건에서 나일론 섬유에 대 해서는 일반적인 산성염료 염색이 이루어지고, 면 섬유
에 대해서는 동일한 산성염료가 반응성염료와 유 사한 방식으로 공유결합을 할 수 있도록 하여 반응

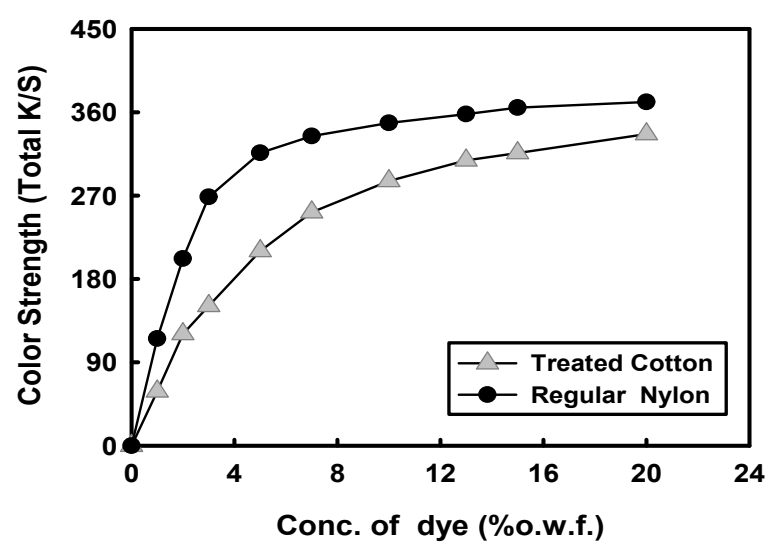

Fig. 9. Build-up properties of Acid Blue 127:1 on DBDCBS treated cotton and nylon fabrics. (DBDCBS ; $10 \%$ o.w.f., $\mathrm{pH} ; 4$, Temp. ; $100^{\circ} \mathrm{C}$, Time ; 60min)

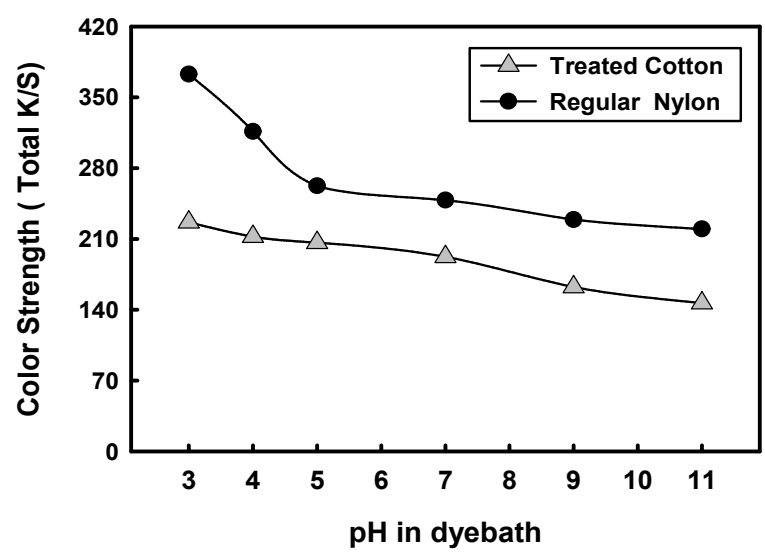

Fig. 10. Effect of $\mathrm{pH}$ on the dyeing with Acid Blue 127:1 of DBDCBS treated cotton and nylon fabrics. (DBDCBS ; 10\% o.w.f., Dye ; $5 \%$ o.w.f., Temp. ; $100^{\circ} \mathrm{C}$, Time ; 60min)

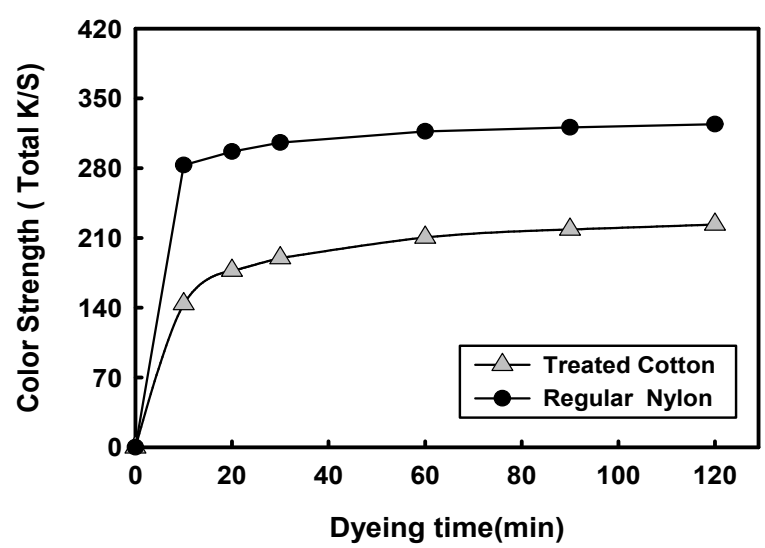

Fig. 11. Effect of dyeing time on the dyeing with Acid Blue 127:1 of DBDCBS treated cotton and nylon fabrics . (DBDCBS ; 10\% o.w.f., Dye ; 5\% o.w.f., pH ; 4, Temp. ; $\left.100^{\circ} \mathrm{C}\right)$ 
염색되므로 이들 두 직물은 비교적 단독적으로 재 현성 있게 염색되어 두 직물 서로간의 염색성에 그 다지 영향을 끼치지 않고 있음을 알 수 있다. 따라 서 이러한 결과를 바탕으로 $\mathrm{DBDCBS}$ 를 적용함으로 써 셀룰로오스 섬유와 나일론 섬유의 복합소재에 대한 완전 일욕염색이 가능할 것으로 보인다.

\subsection{2 나일론/면 교직물의 일욕염색 특성}

앞서 나일론/면 교직물을 이루는 두 소재인 별도 의 나일론 직물과 면직물을 각 조건별로 One-bath process 일욕염색한 후 이들 직물별 염색성을 검토 한 결과 일욕 내에서 아미노기 함유 산성염료에 대 하여 두 직물 서로간의 염색성에 그다지 영향을 끼치 지 않으면서 각각 독립적으로 우수한 염색성을 보이 고 있다. 따라서 이러한 결과를 바탕으로 별도의 나 일론과 면직물을 이용하여 일욕염색하는 것이 아니라 실제 경위사가 각각 나일론 섬유와 면섬유로 이루어 진 나일론/면 교직물을 이용하여 각 염색조건별로 Onebath process 일욕염색 특성을 검토해 보았다.

Fig. 12 는 나일론/면 교직물을 각 $5 \%$ o.w.f.의 아 미노기 함유 산성염료 Acid Blue 127:1와 Acid violet 19 를 사용하여 $\mathrm{pH} 4,100^{\circ} \mathrm{C}$ 조건에서 One-bath process 일욕염색하는 경우 DBDCBS 처리 및 미처리 교직 물의 염색성을 비교하여 나타낸 것으로, DBDCBS 처리한 나일론/면 교직물의 색상강도는 미처리 경우 보다 2 배 이상의 높은 색상강도를 나타내고 있다. 이것은 일욕염색 과정 중 $\mathrm{DBDCBS}$ 를 적용하는 경 우 교직물의 면섬유 부분에 $\mathrm{DBDCBS}$ 가 처리됨으로 서 산성염료의 아미노기가 결합하게 되므로 면섬유 역시 산성염료에 의하여 염색되어 나일론/면 교직 물의 염색성은 크게 증가함을 알 수 있다.

나일론/면 교직물의 One-bath process에 의한 일욕 염색성을 구체적으로 확인하기 위하여 DBDCBS 처 리 과정 후 색상강도가 보다 우수하게 나타나고 있 는 Acid Blue 127:1 아미노기 함유 산성염료를 이용 하여 온도별, 농도별, $\mathrm{pH}$ 별 및 시간별의 각 처리조 건별로 염색하고 이들의 염색특성을 DBDCBS 미처 리 나일론/면 교직물과 비교해 보았다.

Fig. 13은 Acid Blue 127:1 사용하여 나일론/면 교직 물의 일욕염색시 $\mathrm{DBDCBS}$ 를 처리한 경우와 미처리 한 경우 $50^{\circ} \mathrm{C} \sim 110^{\circ} \mathrm{C}$ 의 범위 내에서 각 온도별로 염색한 이들 교직물들의 염색성을 비교하여 나타낸 것이다. 그 결과 모든 나일론/면 교직물은 온도가 증가할수록 색상강도는 서서히 증가하나 $80^{\circ} \mathrm{C}$ 이상 에서는 증가 폭이 매우 미미하여 색상강도는 거의 비슷하게 나타나고 있어 온도에 의한 영향이 비교 적 없음을 알 수 있다. DBDCBS 처리한 나일론/면
교직물은 미처리한 나일론/면 교직물에 비하여 전 체온도에 걸쳐 염색성이 크게 향상되었다. 이것은 앞서 언급한 바와 마찬가지로 $\mathrm{DBDCBS}$ 처리에 의 하여 나일론/면 교직물의 면섬유 부분이 아미노기 함 유 산성염료와 견고하게 결합하여 반응염색 되어 전체적으로 색농도가 증가했기 때문이다.

Fig. 14는 나일론/면 교직물의 일욕염색시 Acid Blue 127:1 산성염료 농도별로 염색한 각 직물들의 색상강도를 비교하여 나타낸 것이다. 그 결과 사용 한 전체 염료농도에 걸쳐 One-bath process에 의한 일욕염색시 DBDCBS가 처리되는 나일론/면 교직물 의 색상강도는 미처리 교직물에 비하여 크게 증가 하여 DBDCBS 처리 나일론/면 교직물의 염색성이 더욱 우수하게 나타나고 있다. $\mathrm{DBDCBS}$ 처리된 나 일론/면 교직물에 대하여 모든 산성염료의 염착량은 염료의 농도가 증가할수록 지속적으로 증가하다가 $10 \%$ o.w.f.이상에서는 거의 완만하게 증가하고 있다.

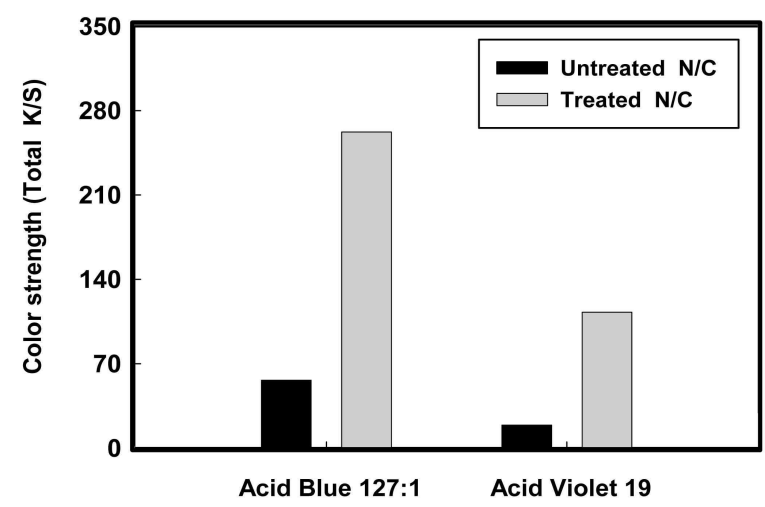

Fig. 12. Color strength of acid dye on untreated and treated nylon/cotton blend fabrics by DBDCBS. (DBDCBS ; 10\% o.w.f., Dye ; 5\% o.w.f., Temp. ; $100^{\circ} \mathrm{C}$, Liq. Ratio ; pH 4, 1:50)

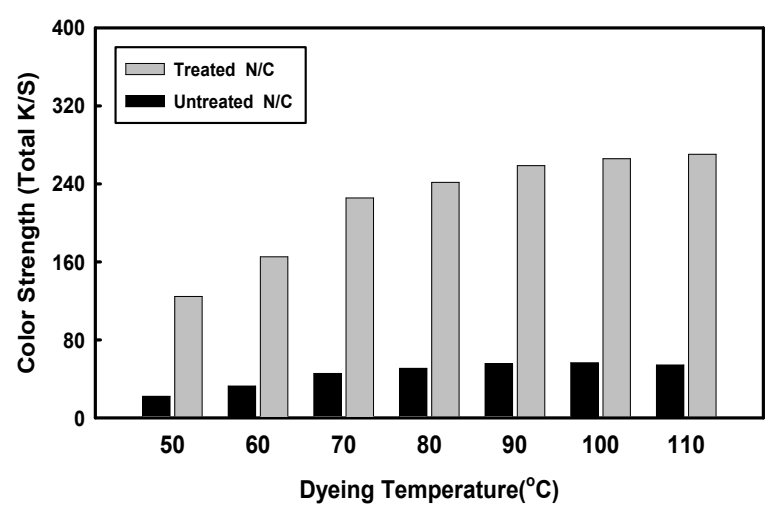

Fig. 13. Effect of dyeing temperature on the dyeing with Acid Blue 127:1 of the nylon/cotton blend fabrics treated and untreated with the DBDCBS. (DBDCBS ; 10\% o.w.f., Dye ; $5 \%$ o.w.f., pH ; 4, Time ; 60min) 


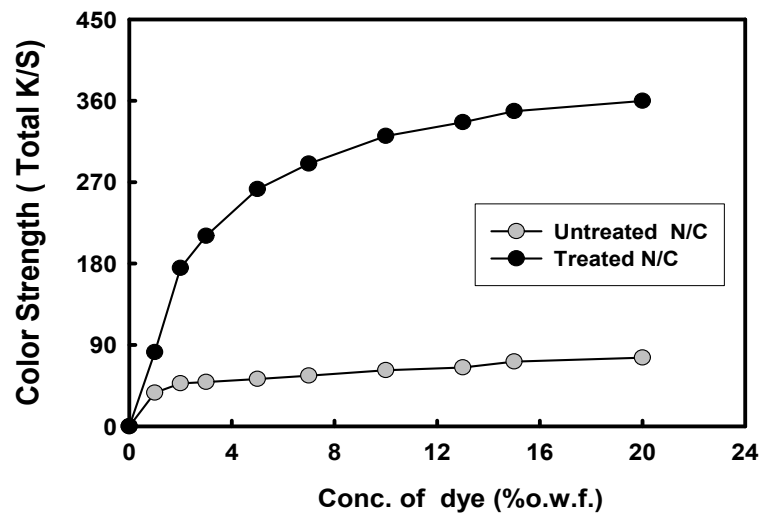

Fig. 14. Build-up properties of Acid Blue 127:1 on the nylon/cotton blend fabrics treated and untreated with the DBDCBS. (DBDCBS ; $10 \%$ o.w.f., pH ; 4, Temp. ; $100^{\circ} \mathrm{C}$, Time ; 60min)

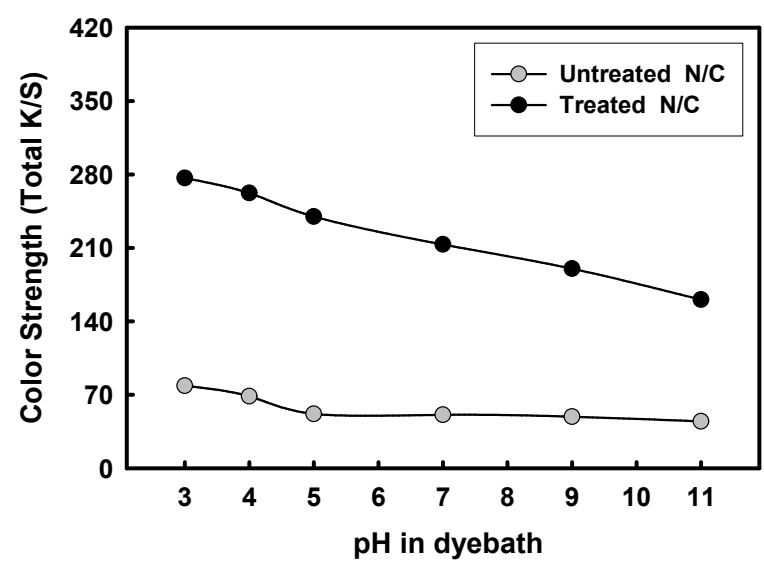

Fig. 15. Effect of $\mathrm{pH}$ on the dyeing with Acid Blue $127: 1$ of the nylon/cotton blend fabrics treated and untreated with DBDCBS.(DBDCBS ; 10\% o.w.f., Dye ; 5\% o.w.f., Temp. ; $100^{\circ} \mathrm{C}$, Time ; 60min)

Fig. 15는 염욕의 $\mathrm{pH}$ 를 3 11까지의 범위 내에서 변화시켜가며 Acid Blue 127:1를 사용하여 일욕염색 한 나일론/면 교직물의 염색성을 조사하여 나타낸 것 으로 일욕염색시 $\mathrm{DBDCBS}$ 가 처리된 나일론/면 교직 물의 염색성은 미처리 교직물 보다 전체 $\mathrm{pH}$ 영역에 걸쳐 매우 높게 나타나고 있다. $\mathrm{DBDCBS}$ 가 처리된 나일론/면 교직물의 경우는 알칼리 영역 보다는 산 성영역으로 갈수록 산성염료의 염착성이 현저히 증 가하는 것을 알 수 있으며 $\mathrm{DBDCBS}$ 미처리교직물 은 알칼리 영역으로 갈수록 염색성이 감소하는경향은 보이지만 그 차이는 매우 미미하다.

Fig. 16은 One-bath process 일욕염색시 나일론/면 교직물의 염색시간별 염색성을 나타낸 것으로 각 산성염료에 대한 염색속도는 모든 경우 30 분 이내 에 거의 평형에 이름을 알 수 있다.

이상에서 살펴본 바와 같이 아미노기를 함유하는

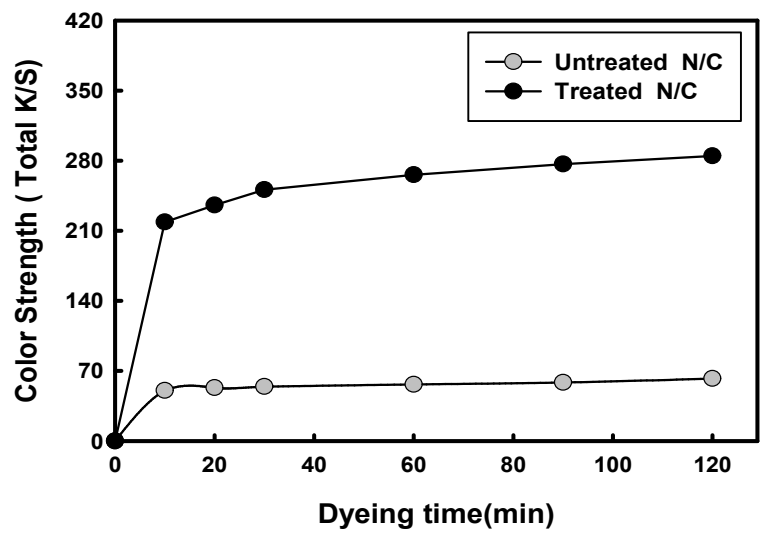

Fig. 16. Effect of dyeing time on the dyeing with Acid Blue $127: 1$ of the nylon/cotton blend fabrics treated and untreated with the DBDCBS. (DBDCBS ; 10\% o.w.f., Dye ; $5 \%$ o.w.f., $\mathrm{pH} ; 4$, Temp. ; $100^{\circ} \mathrm{C}$ )

단일 산성염료만을 사용하여 나일론/면 교직물을 일 욕염색하는 경우 One-bath process 일욕염색과정에 서 면섬유 부분에 $\mathrm{DBDCBS}$ 가 처리되는 나일론/면 교직물은 아미노기 함유 산성염료에 대하여 매우 우수한 염색성을 나타내고 있으며 이러한 염색방법 을 활용하여 나일론/면 복합소재에 대한 완전 일욕 일단 염색이 가능함을 확인할 수 있다.

\section{$3.4 \mathrm{DBDCBS}$ 이용 나일론/면 복합소재의 일욕염 색물의 인장강도 측정}

Fig. 17은 DBDCBS 적용 One-bath process 방법으 로 일욕염색 전, 후 나일론/면 교직물의 인장강도를 비교하여 나타낸 것으로 염색한 나일론/면 교직물의 인장강도는 염색되지 않은 직물에 비하여 경, 위사 방향으로 모두 약간 감소하고 있다. 이는 염색처리 과정의 물리화학적인 영향에 의한 것으로 결과로 여겨지며 이러한 인장강도의 미미한 감소결과는 실 용적인 면에서는 무시할 정도의 수준이다.

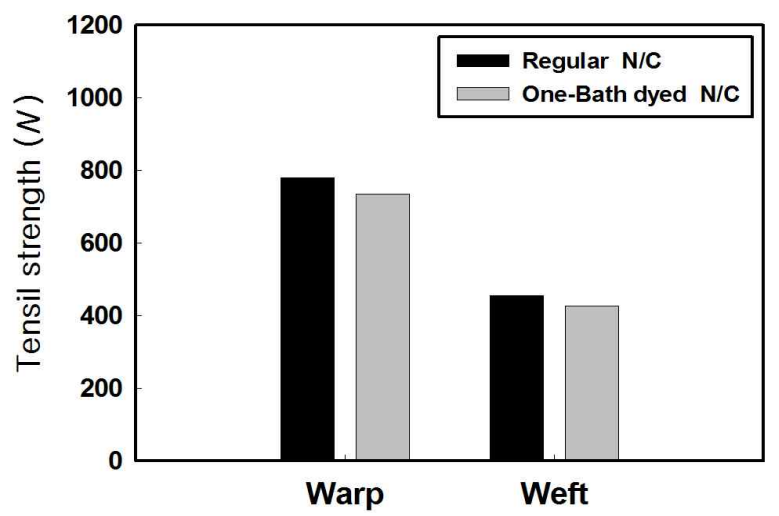

Fig. 17. Tensile strength of the nylon/cotton blend fabrics dyed and undyed with Acid Blue 127:1 in one-bath dyeing process. 
따라서 $\mathrm{DBDCBS}$ 를 이용한 일욕염색 방법 적용 시 나일론/면 교직물의 인장강도 변화는 크지 않음 을 알 수 있다.

$$
\text { 4. 결 론 }
$$

전보 ${ }^{8-10)}$ 의 연구내용을 토대로 본 연구에서는 나 일론/면 복합소재 염색시 한 종류의 산성염료를 사 용하여 서로 다른 두 소재에 동시에 염색 가능한 완전 일욕염색법을 시도하고자 이종 이반응형 화합 물(DBDCBS)을 적용하였다.

먼저 저온의 알칼리 조건에서 면섬유 부분과 공 유결합 가능하고 고온의 산성조건에서 아미노기를 가지는 산성염료와 공유결합 가능한 이종 이반응형 합성 화합물(DBDCBS)이 처리된 면직물의 경우 아 미노기 함유 산성염료에 대하여 우수한 염색성을 나타낸다.

나일론/면 교직물을 이루는 각각의 나일론 섬유와 면섬유 단독직물을 아미노기 함유 단일 산성염료를 사용하여 One-bath process 일욕염색시 나일론 직물 과 $\mathrm{DBDCBS}$ 가 처리된 면직물은 최적 일욕 염색조건 (3-5\% o.w.f., $\mathrm{pH} 4,100^{\circ} \mathrm{C}$ 내외)에서 서로 독립적으로 염색되어 겉보기 동색상을 띄고 있으므로 두 직물의 One-bath process 완전 일욕 염색이 가능하다.

이러한 결과를 바탕으로 나일론/면 교직물에 적용 한 결과 $\mathrm{DBDCBS}$ 처리한 교직물의 경우 역시 비슷한 최적 염색조건 $\left(\mathrm{pH} 4,100^{\circ} \mathrm{C}\right)$ 에서 아미노기 함유 산성 염료에 대하여 우수한 염색성을 나타낸다.

그리고 One-bath process 일욕염색 전, 후 직물의 인장강도 변화는 거의 나타나지 않아 결과적으로 이 종 이반응형의 브릿지 화합물(DBDCBS)을 면섬유 부 분에 적용시 물성이 안정하다.

\section{참고문헌}

1. J. Shore, "Dyeing of Blended Textiles", Korea Dyeing Technology Center, pp.149-227, 2006.

2. M. Clark, "Handbook of Textile and Industrial Dyeing, vol.2: Applications of Dyes", Woodhead Publishing, pp.147-172, 2011.

3. S. D. Kim, J. L. Lee, C. H. Ahn, K. S. Kim, and K. S. Lee, Dyeing of N/P Union Fabric with Reactive Disperse Dyes, Textile Coloration and Finishing(J. of Korean Soc. Dyers \& Finishers), 16(1), 26-33 (2004).
4. S. J. Kim, D. W. Jeon, and J. I. Lee, Dyeing Properties of Cotton/Polyester Composite Yarn in Different Yarn Testing Processes-Focused on One/Two Bath Dyeing Systems with Reactive/Disperse dyes, J. Korean Soc. Clothing \& Textiles, 30(2), 275-285(2006).

5. A. E. Huseyin and A. Pervin, Dye Selection for Alkaline One-step Disperse/Reactive Dyeing of Polyester/ Cotton Blends-Alkaline Disperse Dyes and Mononicotinate Reactive Dyes were Found to withstand Alkaline One-step Dyeing, AATCC Review, 4(7), 23 (2004).

6. E. R. Trotman, "Dyeing and Chemical Technology of Textile Fibres, $6^{\text {th }} E d$. .", John Wiley and Sons, Inc., New York, pp.447-454, 1984.

7. J. Shore, "Colorants and Auxiliaries, Vol. 1, Colorants", Society of Dyers and Colourists, West Yorkshire, pp.307-311, 1990.

8. T. K. Kim, S. H. Yoon, and M. K. Kim, The Disperse Dyeing of Polyester/Cotton Blend Using a Hetero -bifunctional Bridge Compound (I), Textile Coloration and Finishing(J. of Korean Soc. Dyers \& Finishers), 18(3), 121-129(2006).

9. M. K. Kim, S. K. Yoon, T. K. Kim, J. S. Bae, and N. S. Yoon, Dyeing of Cotton and Polyester/ Cotton Blend with Disperse Dyes Using Sodium 2-(2,3-dibromopropionylamino)-5-(4,6-dichloro1,3,5-triazinylamino)-benzene sulfonate, Fibers and Polymers, 7(4), 352-357(2006).

10. M. K. Kim, S. K. Yoon, T. K. Kim, and N. S. Yoon, The Disperse Dyeing of Polyester/Cotton Blend Using a Hetero-bifunctional Bridge Compound $(\Pi)$, Textile Coloration and Finishing(J. of Korean Soc. Dyers \& Finishers), 19(1), 1-11(2007).

11. Y. S. Kim, S. J. Lee, and Y. A. Son, Dyeing Properties of Acid and Reactive Dye for Super Soft Angora/ PET, Nylon Blended Fabric, Textile Coloration and Finishing(J. of Korean Soc. Dyers \& Finishers), 22(4), 332-340(2010).

12. Y. S. Shin, A. R. Cho and D. I. Yoo, Natural Indigo Dyeing of Cotton Fabric : One-step Reduction/ Dyeing Process, Textile Coloration and Finishing(J. of Korean Soc. Dyers \& Finishers), 22(2), 101-109 (2010). 